\title{
Determination of Chlorine in Bituminous Coal and Its Behavior during Carbonization
}

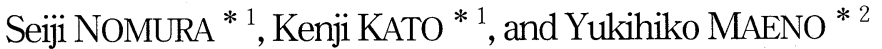 \\ (Received January 6, 2003)
}

\section{原料炭中の塩素の定量と熱分解過程における原料炭中塩素の挙動 野村誠治*1, 加藤健次*1, 前野幸彦*2}

\begin{abstract}
Chlorine content of bituminous coal was determined and its behavior during carbonization was investigated. The chlorine content in the metallurgical coals used in this experiment was between 100 and $1,500 \mathrm{ppm}$. Most chlorine in coal and coke was removed by washing with water. $\mathrm{CaO}$ addition to coal increased the chlorine residue ratio in coke. The residue ratio of chlorine in coke increased with increasing $\mathrm{Ca}$ content in coal. This is considered because chlorine in coal is released as $\mathrm{HCl}$, which is trapped in coke again in the form of $\mathrm{CaCl}_{2}$. The chlorine residue ratio of coke produced in actual coke oven was higher than that of coke produced in laboratory scale tube furnace. This is considered because released gas from coal has more chances to contact with calcium in the actual coke oven than in the tube furnace. Furthermore the removal of chlorine from $\mathrm{NaCl}$ was promoted by co-carbonization of $\mathrm{NaCl}$ with coal. This implies that $\mathrm{H}_{2} \mathrm{O}$ derived from coal decomposition may help chlorine to be released.
\end{abstract}

\section{Key Words}

Coal, Coke, Chlorine, Carbonization, Calcium

\section{1. 緒 言}

石炭中に含まれる塩素は，燃焼炉やガス化プロセスにおい て，腐食等の問題を引き起こす原因となることが知られてい る 1) -3)。このため, 石炭中塩素の存在形態 1) 3) 4), および, $200 \sim 300{ }^{\circ} \mathrm{C}$ の低温（空気中あるいは不活性ガス䨌囲気下）で 石炭を熱処理した場合の石炭中塩素の脱離挙動について ${ }^{4)}$ ７) は，従来より多くの報告がなされている。

一方，鉄鋼業における高炉製銑法においては，コークス炉 で原料炭を乾留してコークスを製造し，コークスを主な還元 材として高炉に装入し銑鉄を製造しているが，コークス中の 塩素は高温下で塩化水素として脱離するため, 高炉設備の腐 食問題を生じる可能性がある。しかしながら，これまで鉄鋼 用原料炭中塩素の熱分解過程に扮ける脱離挙動や，原料炭お よびコークス中塩素の定量についてはほとんど検討されたこ とがなく, Mianowski ら ${ }^{8)}$ がポーランド炭を対象に, 不活性 ガス䨌囲気下において $1,000{ }^{\circ} \mathrm{C}$ まで熱処理を行い，熱処理温度

* 1 Environment \& Process Technology Center, Nippon Steel Corporation

Shintomi 20-1, Futtsu-shi, Chiba 293-8511, Japan

* 2 Kimitsu Works, Nippon Steel Chemical Co., Ltd. Kimitsu 1, Kimitsu-shi, Chiba 299-1141, Japan
の上昇とともに塩素の脱離が増加することを報告している程 度である。また，これまで検討された石炭は比較的塩素含有 量の多い米国炭や英国炭が中心であり，日本の鉄鋼メーカー で治金用コークス製造用の原料炭として主に用いられている 豪州炭やカナダ炭に含まれる塩素の挙動についてはほとんど 検討がなされていない。

今後高炉の長寿命化が指向される中で，高炉装入物中塩素 についての検討は重要な課題の一つである。そこでここでは, 新日本製鐵で使用されている治金用コークス製造用の原料炭 を対象とし，石炭・コークス中塩素の定量，コークス炉での 石炭乾留過程，すなわち石炭熱分解過程における塩素の挙動 について検討した結果について報告する。

\section{2. 実験方法}

\section{1 供試試料}

実験には，石炭化度 $\left(\overline{\mathrm{R}}_{0}\right) 0.75 \sim 1.58 \%$ ，揮発分 18.3

\footnotetext{
* 1 新日本製鐵株式會社 環境・プロセス研究開発センター 製銑研究開発部 于 293-8511 千葉県富津市新富 20-1

*2 新日鐵化学株式会社 君津製造所 干 299-1141 千葉県君津市君津 1
} 
35.5 dry, mass \%の 15 種類の鉄鋼用原料炭（A〜O炭）を用 いた。実験に用いた石炭試料の性状を Table 1 に示す。

\section{2 石炭, 加熱処理炭およびコークスの塩素濃度測定}

塩素濃度は，燃焼管燃焼 $\left(1,350{ }^{\circ} \mathrm{C}\right)$ 酸素法処理一イオン交 換クロマトグラフィー法により測定した。燃焼管燃焼はJIS M 8813 に記載の全いおうの燃焼容量法に準じ， $0.2 \mathrm{~g}$ の試料を酸 素気流中 $1,350{ }^{\circ} \mathrm{C}$ で燃焼させた。燃焼ガスは $1 / 500 \mathrm{~N}$ の $\mathrm{NaOH}$ 水溶液 $80 \mathrm{ml}$ に吸収させ，適量にメスアップした後，イオン交 換クロマトグラフィー（日本ダイオネクス(株) 製 DIONEX 2000i/sp 型）により塩素濃度を測定した。なお，イオン交換 クロマトグラフィーでの測定可能塩素濃度範囲は 0.1 $10 \mathrm{ppm}$ であり，濃度分析值の有効数字は 3 桁である。塩素定 量は 2 回実施し, 分析誤差 (2 回の測定值の差/2 回の測定值 の平均値 $\times 100)$ は $5 \%$ 以内であった。

\section{3 石炭およびコークス中塩素の水浸出}

$38 \mu \mathrm{m}$ (400mesh) 以下に粉砕した石炭あるいはコークス 試料 (A， B，C，F， G，Lの 6 種類） $0.3 \sim 0.5 \mathrm{~g}$ を $150 \mathrm{ml}$ の 純水中に懸濁させ， 24 時間擋挥することにより石炭およびコ ークス中の水溶性塩素を浸出した。その後, 懸濁液をメンブ レンフィルター（孔径 $1 \mu \mathrm{m} ）$ を用いてろ過し，ろ液の塩素 濃度をイオン交換クロマトグラフィーにより測定した。

\section{4 コークス試料および加熱処理試料の調整}

$1 \mathrm{~mm}$ 以下 100 \%に粉砕した石炭試料 $1.5 \mathrm{~g}$ をアルミナ製の燃 焼ボート $(85 \mathrm{~mm}$ 長 $\times 10 \mathrm{~mm}$ 幅 $\times 10 \mathrm{~mm}$ 深さ $)$ に入れて石英 管 $($ 内径 $63 \mathrm{~mm} \times$ 長さ $600 \mathrm{~mm}$ ) 内に設置し，Fig. 1 に示す様 に赤外線イメージ炉 (真空理工 (株) 製 RHL-P610 型，加熱ゾー ン長 $265 \mathrm{~mm}$ ）を用いて窒素気流中（1Nl/min）で加熱した。 試料温度は，試料層中央部に設置した熱電対により調整した。 試料は $10{ }^{\circ} \mathrm{C} / \mathrm{min}$ で加熱し, $900{ }^{\circ} \mathrm{C}$ 到達後直ちに急冷してコー

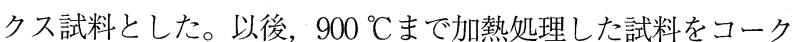
ス試料と呼ぶこととする。

また，熱分解過程における塩素挙動に及ほすすカシウムの 影響について検討するため, 酸化カルシウム試薬 $(\mathrm{CaO}$ ：関 東化学製特級, 純度>98\%）をF炭に化合物質量ベースで $5 \%$ 添加してコークス試料を調整した。石炭と試薬の混合物は, スパチュラで採取した試薬を石炭と短時間で擋はん混合する ことにより調整した後，直ちに加熱処理を行った。以下の試 薬の添加方法も同様とした。

加熱処理試料中塩素質量と石炭中塩素質量の比を, 石炭由 来塩素残留率と定義し, 次式により求めた。ここで, 固体試 料中塩素濃度の表示として mg-Cl/ $\mathrm{kg}$-固体 (dry) を $\mathrm{ppm}$ と表 示することとする。

石炭由来塩素残留率 $(\%)=$ (加熱処理試料中塩素質量) $/$ (石炭中塩素質量) $\times 100=$ (加熱処理試料中塩素濃度 $(\mathrm{ppm})) \times($ 加熱処理試料の歩留 $(\%)) /($ 石炭中塩素濃度 $(\mathrm{ppm}))$

以後，特に断りがない場合を除き，石炭由来塩素残留率を 単に塩素残留率と呼ぶこととする。

さらに，塩素残留率に及ぼす熱処理温度および保持時間の 影響について検討するため， $\mathrm{H}$ 炭および $\mathrm{K}$ 炭については，昇 温速度 $5{ }^{\circ} \mathrm{C} / \mathrm{min}$ で所定の熱処理温度 $\left(350{ }^{\circ} \mathrm{C}, 600{ }^{\circ} \mathrm{C}, 900{ }^{\circ} \mathrm{C}\right)$

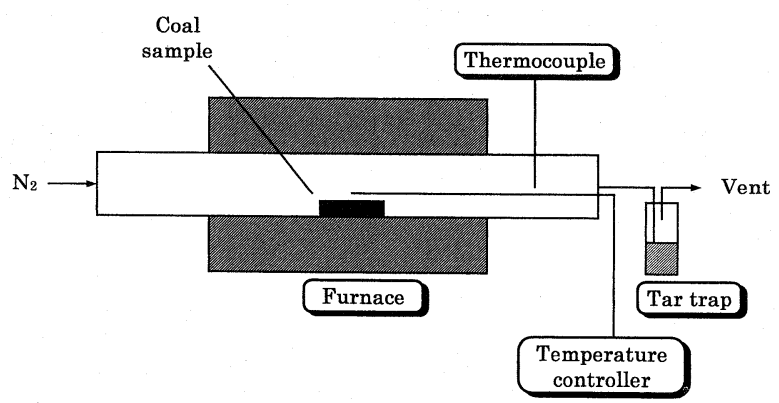

Fig. 1 Experimental apparatus for carbonization

Table 1 Characterization data for the coals used

\begin{tabular}{|c|c|c|c|c|c|c|c|c|c|}
\hline \multirow[t]{3}{*}{ Coal } & \multirow[t]{3}{*}{ Country } & \multirow{2}{*}{\multicolumn{2}{|c|}{$\begin{array}{l}\text { Proximate analysis } \\
\text { (mass\% db) }\end{array}$}} & \multirow{2}{*}{\multicolumn{2}{|c|}{$\begin{array}{c}\text { Elemental analysis } \\
\text { (mass\% daf) }\end{array}$}} & \multirow{3}{*}{\begin{tabular}{|c|}
$\begin{array}{c}\text { Dilatometry } \\
\text { total dilatation } \\
\text { (vol.\%) }\end{array}$ \\
\end{tabular}} & \multirow{3}{*}{$\begin{array}{l}\text { Gieseler plastometry } \\
\text { maximum fluidity } \\
\text { (log MF/ddpm) }\end{array}$} & \multicolumn{2}{|c|}{ Petrographic analysis } \\
\hline & & & & & & & & \multirow{2}{*}{\begin{tabular}{|c|} 
Reflectance \\
(av.) (\%)
\end{tabular}} & \multirow{2}{*}{$\begin{array}{c}\text { Total inerts } \\
(\mathrm{vol} \%)\end{array}$} \\
\hline & & VM & Ash & $\mathrm{C}$ & $\mathrm{H}$ & & & & \\
\hline A & Russia & 18.3 & 10.4 & 91.8 & 4.7 & 60 & 1.42 & 1.58 & 26.5 \\
\hline $\mathrm{B}$ & Australia & 19.9 & 9.9 & 90.1 & 4.9 & 76 & 2.33 & 1.46 & 27.6 \\
\hline $\mathrm{C}$ & Australia & 20.8 & 11.2 & 90.0 & 4.9 & 94 & 2.44 & 1.36 & 29.3 \\
\hline $\mathrm{D}$ & Canada & 23.0 & 10.3 & 89.6 & 4.7 & 58 & 3.59 & 1.33 & 37.0 \\
\hline $\mathrm{E}$ & China & 25.0 & 10.2 & 88.1 & 4.9 & 108 & 3.58 & 1.30 & 40.1 \\
\hline $\mathrm{F}$ & Australia & 23.8 & 9.1 & 90.0 & 4.9 & 119 & 2.82 & 1.22 & 31.0 \\
\hline G & Canada & 25.6 & 10.3 & 90.4 & 4.8 & 54 & 2.44 & 1.21 & 41.9 \\
\hline $\mathrm{H}$ & Australia & 23.8 & 9.9 & 89.5 & 5.0 & 106 & 2.99 & 1.18 & 35.1 \\
\hline I & Canada & 26.1 & 10.2 & 89.5 & 5.0 & 55 & 2.60 & 1.16 & 39.4 \\
\hline $\mathrm{J}$ & Canada & 27.3 & 9.2 & 87.6 & 5.2 & 87 & 2.50 & 1.08 & 25.0 \\
\hline $\mathrm{K}$ & USA & 34.2 & 7.7 & 86.5 & 5.4 & 181 & 4.09 & 0.91 & 25.2 \\
\hline $\mathrm{L}$ & South Africa & 32.4 & 8.3 & 84.9 & 5.1 & 0 & 1.13 & 0.91 & 43.2 \\
\hline $\mathrm{M}$ & China & 35.5 & 8.4 & 85.6 & 5.4 & 35 & 3.07 & 0.90 & 40.5 \\
\hline $\mathrm{N}$ & Australia & 34.4 & 7.1 & 83.7 & 5.5 & 148 & 3.49 & 0.86 & 21.3 \\
\hline $\mathrm{O}$ & Australia & 35.5 & 10.0 & 83.8 & 5.5 & 29 & 1.97 & 0.75 & 26.9 \\
\hline
\end{tabular}


まで加熱した後に急冷し，熱処理温度を変えた試料を調整し た。また $\mathrm{H}$ 炭については, 昇温速度 $5{ }^{\circ} \mathrm{C} / \mathrm{min} て ゙ ~ 360{ }^{\circ} \mathrm{C}$ まで加 熱した後, $360{ }^{\circ} \mathrm{C} て ゙ ~ 6$ 時間または 17 時間保持後に急冷した試 料を調整した。

また, 新日鐵化学 (制) 君津製造所の実機コークス炉において, コークス炉用配合炭㧍よびコークスをサンプリングし，各々 の塩素濃度を測定して塩素残留率を求めた。

\section{5 石炭と無機塩化物の共炭化}

石炭と無機塩化物を共炭化した場合の塩素の挙動について も検討した。無機塩化物としては, 塩化ナトリウム $(\mathrm{NaCl}$ : 関東化学製 1 級, 純度 $>99.0 \%)$, 塩化カルシウム $\left(\mathrm{CaCl}_{2}\right.$ : 関東化学製 1 級, 純度 $>95.0 \%)$ ，塩化マグネシウム $\left(\mathrm{MgCl}_{2} \cdot 6 \mathrm{H}_{2} \mathrm{O}\right.$ ：関東化学製 1 級，純度 $\left.>98.0 \%\right)$ を用いた。

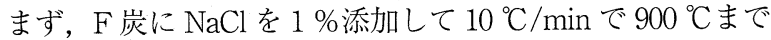
加熱したコークス試料を調整した。さらに， $\mathrm{NaCl}$ に加えて， $\mathrm{CaO}$ 試薬を 5 \% 添加してコークス試料を調整した。また， $\mathrm{NaCl}$ 単独でも同様の条件で熱処理し，重量変化を測定した。

また熱処理温度の影響を調べるため， $\mathrm{H}$ 炭に $\mathrm{NaCl} 1 \%$ ， $\mathrm{CaCl}_{2} 1 \%$ ，あるいは $\mathrm{MgCl}_{2} \cdot 6 \mathrm{H}_{2} \mathrm{O} 2 \%$ を添加し, 昇温速度 $5{ }^{\circ} \mathrm{C} / \mathrm{min}$ で所定の熱処理温度 $\left(360{ }^{\circ} \mathrm{C}, 600{ }^{\circ} \mathrm{C}, 900{ }^{\circ} \mathrm{C}\right)$ まで 加熱した後に急冷し，熱処理温度を変えた試料を調整した。 $\mathrm{MgCl}_{2} \cdot 6 \mathrm{H}_{2} \mathrm{O}$ の添加率を $2 \%$ \%たのは，石炭に加える塩素量 をほほ同じレベルにそろえるためである（ $\mathrm{NaCl}, \mathrm{CaCl}_{2}$, $\mathrm{MgCl}_{2} \cdot 6 \mathrm{H}_{2} \mathrm{O}$ 中の塩素含有率はそれぞれ $60.7 \%$ ， $63.9 \%$ ， $34.9 \%) 。 さ ら に$ 保持時間の影響を調べるため, $\mathrm{H}$ 炭に $\mathrm{NaCl}$ $1 \%, \mathrm{CaCl}_{2} 1 \%$ ，あるいは $\mathrm{MgCl}_{2} \cdot 6 \mathrm{H}_{2} \mathrm{O} 2 \%$ を添加した試料に

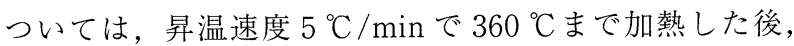
$360^{\circ} \mathrm{C} て ゙ 6$ 時間または 17 時間保持後に急冷した試料も調整した。
ここで，無機塩化物由来塩素の残留率を次式により求めた。 無機塩化物由来塩素の残留率 $(\%)=[$ (加熱処理試料中塩素 質量 $)-($ 石炭中塩素質量 $) \times($ 石炭由来塩素残留率 $(\%) / 100)] /$ (無機塩化物中塩素質量 $) \times 100$

\section{3. 実験結果および考察}

\section{1 原料炭中の塩素濃度}

用いた鉄鋼用原料炭中の塩素濃度 $\left(\mathrm{Cl}_{\mathrm{coal}}\right)$ は炭種により大 きく異なり，約 $100 〜$ 1,500ppm であった（Table 2）。また豪 州炭やカナダ炭の塩素濃度は, 従来報告されている英国炭や 米国炭の塩素濃度 $(>1,000 \mathrm{ppm})^{\left.1{ }^{1}\right)}$ 2) ๖りも低く $1,000 \mathrm{ppm}$ 以 下であった。

炭素含有量と石炭中塩素濃度の関係を Fig. 2 に示す。 Hodges らの総説 ${ }^{11}$ によると, 炭素含有量 $86 \%$ 以上の石炭で は塩素濃度は $2,000 \mathrm{ppm}$ 以下であることが述べられている。本

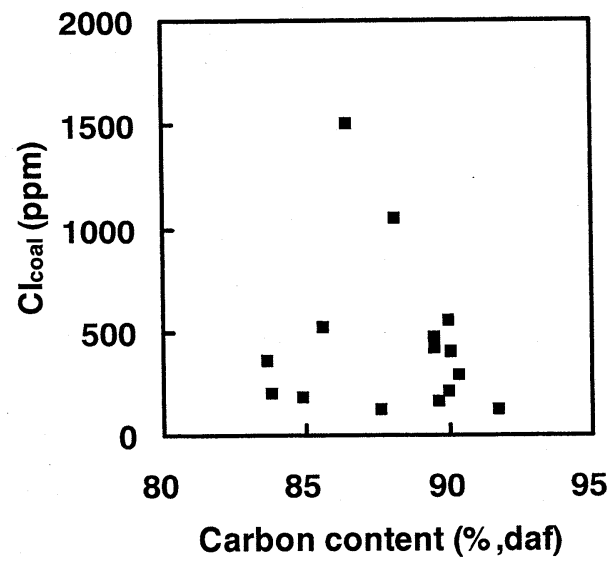

Fig. 2 Relationship between carbon and chlorine in coals

Table 2 Chlorine content in coal and coke

\begin{tabular}{|c|c|c|c|c|c|c|c|c|}
\hline \multirow{2}{*}{ Coal } & \multicolumn{4}{|c|}{ Inorganic constituents in coal } & \multicolumn{2}{|c|}{ Inorganic constituents in coke } & \multirow{2}{*}{$\begin{array}{c}\text { Coke yield } \\
(-)\end{array}$} & \multirow{2}{*}{$\begin{array}{c}\text { Chlorine } \\
\text { residue } \\
\text { ratio } \\
(\%)\end{array}$} \\
\hline & $\begin{array}{l}\mathrm{Na}_{2} \mathrm{O} \\
(\mathrm{ppm})\end{array}$ & $\begin{array}{l}\mathrm{CaO} \\
(\%)\end{array}$ & $\begin{array}{l}\mathrm{Cl}_{\text {coal }} \\
(\mathrm{ppm})\end{array}$ & $\begin{array}{c}\text { Water soluble } \\
\text { chlorine ratio (\%) }\end{array}$ & $\begin{array}{l}\mathrm{Cl}_{\text {coke }} \\
(\mathrm{ppm})\end{array}$ & $\begin{array}{c}\text { Water soluble } \\
\text { chlorine ratio (\%) }\end{array}$ & & \\
\hline $\mathrm{A}$ & 512 & 0.651 & 116 & 83.6 & 66 & 90.9 & 0.833 & 47.4 \\
\hline $\mathrm{B}$ & 755 & 0.245 & 394 & 83.0 & 108 & 92.4 & 0.826 & 22.6 \\
\hline $\mathrm{C}$ & 645 & 0.157 & 550 & 70.4 & 86 & 81.4 & 0.756 & 11.8 \\
\hline $\mathrm{D}$ & 810 & 0.609 & 161 & n.a. & 66 & n.a. & 0.780 & 32.0 \\
\hline $\mathrm{E}$ & 590 & 0.107 & 1,040 & n.a. & 88 & n.a. & 0.745 & 6.3 \\
\hline $\mathrm{F}$ & 278 & 0.194 & 210 & 84.3 & 97 & 90.7 & 0.759 & 35.0 \\
\hline $\mathrm{G}$ & 783 & 0.845 & 290 & 77.6 & 160 & 103.1 & 0.753 & 41.5 \\
\hline $\mathrm{H}$ & 438 & 0.078 & 471 & n.a. & 179 & n.a. & 0.781 & 29.7 \\
\hline $\mathrm{I}$ & 1,357 & 0.667 & 420 & n.a. & 175 & n.a. & 0.755 & 31.4 \\
\hline $\mathrm{J}$ & 373 & 0.203 & 116 & n.a. & 40 & n.a. & 0.741 & 25.6 \\
\hline $\mathrm{K}$ & 848 & 0.104 & 1,500 & n.a. & 245 & n.a. & 0.700 & 11.4 \\
\hline $\mathrm{L}$ & 224 & 0.681 & 177 & 87.3 & 89 & 105.2 & 0.679 & 34.1 \\
\hline $\mathrm{M}$ & 698 & 0.366 & 520 & n.a. & 315 & n.a. & 0.665 & 40.3 \\
\hline $\mathrm{N}$ & 347 & 0.181 & 361 & n.a. & 195 & n.a. & 0.717 & 38.7 \\
\hline $\mathrm{O}$ & 602 & 0.227 & 202 & n.a. & 90 & n.a. & 0.639 & 28.5 \\
\hline
\end{tabular}

n.a. : no data available

Heat treatment condition: $\mathrm{N}_{2}, 10{ }^{\circ} \mathrm{C} / \mathrm{min}, 900{ }^{\circ} \mathrm{C}$ 
実験に用いた石炭もこの範囲に入るが，石炭化度とは特に相 関がない。

Fig. 3 に石炭中の $\mathrm{Na}_{2} \mathrm{O}$ 濃度 $\left(\mathrm{Na}_{2} \mathrm{O}_{\text {coal }}\right.$ : 工業分析による灰 濃度に灰中の $\mathrm{Na}_{2} \mathrm{O}$ 濃度を乗じた值) と塩素濃度の関係を示す。 また Fig. 4 に，Edgcombe ${ }^{6}$ が用いた 29 種類の英国炭（石炭中 塩素濃度 $500 \sim 9,800 \mathrm{ppm}$ ，その内 27 種類が $2,600 \mathrm{ppm}$ 以上） と本実験に用いた石炭について，石炭中の $\mathrm{Na}_{2} \mathrm{O}$ 濃度と塩素濃 度の関係を示す。図より， $\mathrm{Na}_{2} \mathrm{O}$ 濃度が高いほど塩素濃度が高 い傾向にあることがわかる（Fig. 3 中の実線は，塩素濃度測定 值の最大，最小範囲を示す)。これは，従来から言われている ように，石炭中塩素の多くが塩水（ブライン） ${ }^{2)}$ まは塩分 を含んだ地下水に由来している1）2）市ためであると推察され る。

さらに Fig. 3 と Fig. 4 に，石炭中の $\mathrm{Na}$ が全て $\mathrm{NaCl}$ 由来で あると仮定して求めたナトリウム当量塩素濃度 $\left(\mathrm{Cl}_{\text {eq.Na }}\right)$ を破 線で示す。ナトリウム当量塩素濃度は石炭中の $\mathrm{Na}_{2} \mathrm{O}$ 濃度を用 いて下式により求めた。

$\mathrm{Cl}_{\text {eq.Na }}=(35.45 / 22.99) \times(2 \times 22.99 /(2 \times 22.99+16)) \times$ $\mathrm{Na}_{2} \mathrm{O}_{\text {coal }}=1.144 \times \mathrm{Na}_{2} \mathrm{O}_{\text {coal }}$

図より，Edgcombe ${ }^{6)}$ の用いた石炭では，石炭中塩素濃度は

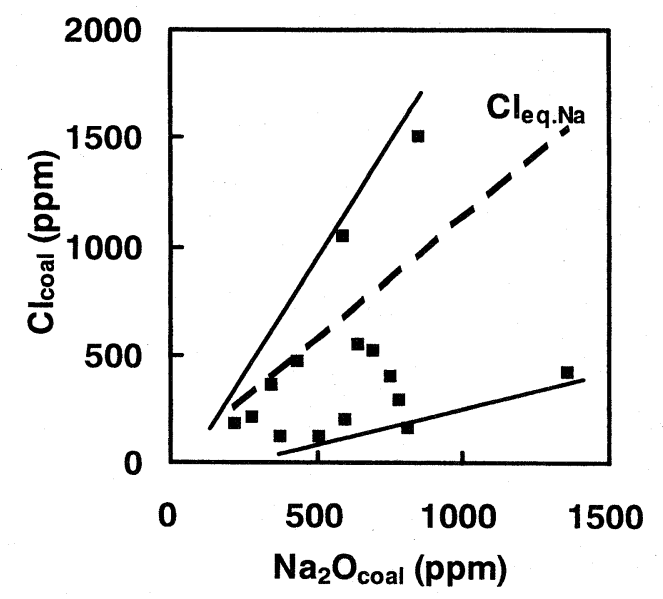

Fig.3 Relationship between sodium and chlorine in coals

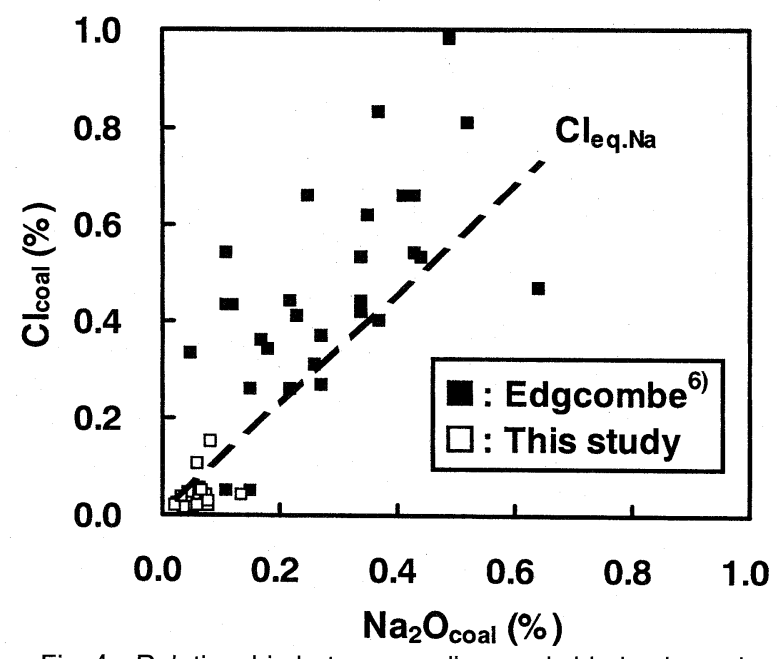

Fig. 4 Relationship between sodium and chlorine in coals
ナトリウム当量塩素濃度よりも若干高いが, 本実験に用いた 石炭では，塩素濃度が高い 2 種類の石炭（E，K）を除いて石 炭中の塩素濃度はナトリウム当量塩素濃度よりも若干低い。 この理由についてはさらに検討が必要である。

\section{2 原料炭中塩素の存在形態}

石炭中の全塩素量に対する水溶性塩素量の割合 (Water soluble chlorine ratio）は, Table 2 に示すように，炭種により異 なるが $70 \%$ 以上が水溶性であった。Edgcomb ${ }^{6)}$ や Fynes ら ${ }^{4)}$ は，塩素含有量の高い英国炭や米国炭に含まれる塩素のほと んど全てが水に浸出することを示しているが，本検討により 日本の鉄鋼メーカーで治金用コークス製造用に用いられてい る原料炭中についても含有塩素の多くが水溶性であることが 明らかとなった。

\section{3 コークス中塩素の存在形態}

Table 2 に示すように，コークス中塩素濃度 $\left(\mathrm{Cl}_{\text {coke }}\right)$ は石炭 中塩素濃度よりも低いことがわかる。これは, 石炭中塩素の 一部が塩化水素として脱離したためと考えられる。また，コ ークス中の塩素は 80 \%以上が水溶性であった。

\section{4 コークス中塩素残留率}

Table 2 に示すように，コークス中塩素残留率は炭種により 大きく異なる。Fig. 5 に，石炭中の $\mathrm{CaO}$ 濃度（工業分析によ る灰濃度に灰中の $\mathrm{CaO}$ 濃度を乗じた值）とコークス中塩素残 留率の関係を示す。図より, $\mathrm{CaO}$ 濃度が高いほどコークス中 塩素残留率が高い傾向にあることがわかる。

また, Fig. 6 に, 実機における配合炭中の $\mathrm{CaO}$ 濃度とコー クス中塩素残留率の関係を示す。図より，実機においても $\mathrm{CaO}$ 濃度が高いほどコークス中塩素残留率が高い傾向にある ことがわかる。

また, Table 3 より, $\mathrm{CaO}$ 添加によりコークス中塩素残留率 が増加し，より多くの塩素が固定されていることがわかる。

この理由は以下のように考えられる。石炭を加熱すると,

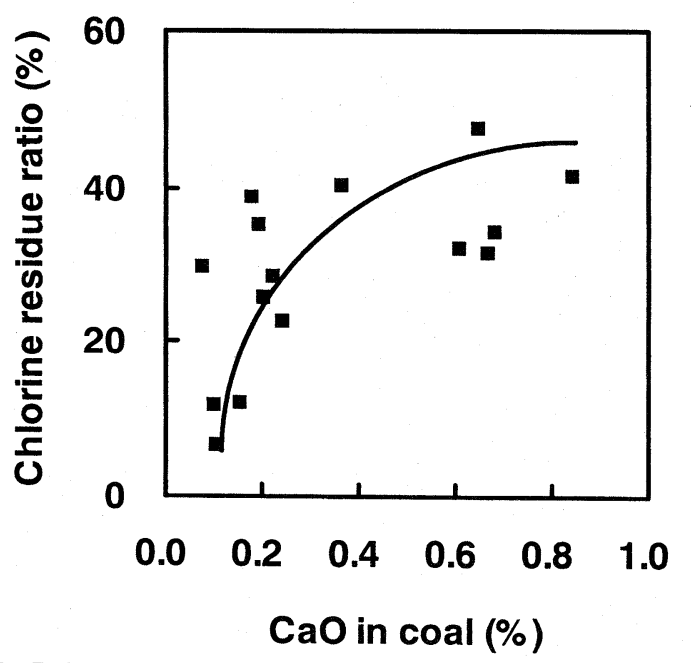

Fig. 5 Relationship between $\mathrm{CaO}$ content in coals and chlorine residue ratio in laboratory scale experiment $\left(10{ }^{\circ} \mathrm{C} / \mathrm{min}, 900{ }^{\circ} \mathrm{C}\right)$ 
石炭中の塩素は塩化水素として脱離することが知られている ${ }^{1) 5) 。 ~}$ 発生した塩化水素の一部は石炭中のカルシウムと反応し, 塩

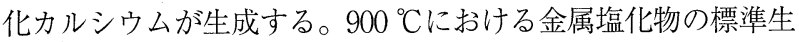
成自由エネルギーを比較すると，石炭中に存在する主な金属 の中では, $\mathrm{Ca}<\mathrm{Na}<\mathrm{Mg}<\mathrm{Al}<\mathrm{Si}<\mathrm{Fe}$ の順であり, カル シウムの塩化物は, 他の金属塩化物よりも熱力学的に高温で 安定である。このため, カルシウム含有量の多い石炭では, 発生した塩化水素が塩化カルシウムとして固定されやすいた め，コークス中塩素残留率が高くなると推察される。

赤外炉と実機を比較すると, 同一の $\mathrm{CaO}$ 濃度でも実機の方 がコークス中塩素残留率が高い傾向にある。これは，赤外炉 と比較して実機では石炭粒子表面からの発生ガスの拡散距離 が長く，石炭およびコークスと接触する確率が高いため，発 生した塩化水素ガスが $\mathrm{CaCl}_{2}$ として再トラップされやすいた めと考えられる。

\section{5 熱処理温度・保持時間が塩素残留率に及ぼす影響}

Fig. 7 に熱処理温度と塩素残留率の関係を示す。図より, 熱 処理温度の上昇とともに塩素残留率が低下することがわかる。 これは Mianowski ら ${ }^{8)}$ の結果と同様である。Fig. 8 に, $360{ }^{\circ} \mathrm{C}$ での保持時間と塩素残留率の関係を示す。これより，保持し

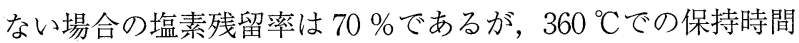
が長いほど塩素残留率が低下し，17 時間後には $15 \%$ まで低下 することがわかる。また，H 炭のコークス中塩素残留率は昇 温速度が遅いほど低くなった $\left(10{ }^{\circ} \mathrm{C} / \mathrm{min}\right.$ で $29.7 \%$ から $5{ }^{\circ} \mathrm{C}$

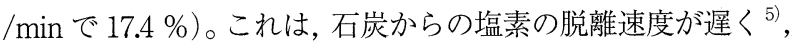
昇温速度が遅く熱処理時間が長い方がより多くの塩素が脱離 するためと考えられる。

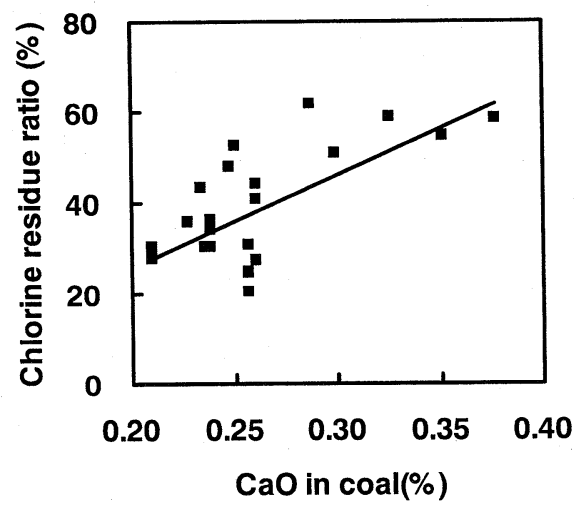

Fig. 6 Relationship between $\mathrm{CaO}$ content in coals and chlorine residue ratio in actual coke oven

\section{6 石炭と無機塩化物を共炭化した場合の塩素残留率}

Table 3 に NaCl を $1 \% \mathrm{~F}$ 炭に添加した場合の試料中塩素濃 度 $\left(\mathrm{Cl}_{\text {coal }}+\mathrm{NaCl}\right)$ およびコークス中塩素濃度を示す。 $\mathrm{NaCl}$ を添 加した場合，コークス中塩素濃度は極めて高い（4,320ppm） が，石炭由来塩素残留率が $\mathrm{NaCl}$ 添加により変化しないと仮定 すると, $\mathrm{NaCl}$ 由来塩素の残留率は約半分程度（54\%）しかな いことがわかる。 $\mathrm{NaCl}$ 単独で同一の条件で熱処理した場合の 重量減少は $1.7 \%$ と極めて小さいことから，石炭との共炭化に より無機塩化物からの塩素の脱離が促進されていると考えら れる。

Herod $5^{5)}$ は, 石炭中の塩素は $\mathrm{HCl}$ として脱離し, 石炭か ら発生する水が水素源であろうと推察している。石炭をイナ 一ト需囲気で熱分解すると, 石炭中のフェノール性水酸基の 分解や水素結合の架橋形成反応により高温でも $\mathrm{H}_{2} \mathrm{O}$ は発生し ${ }^{9)}$,

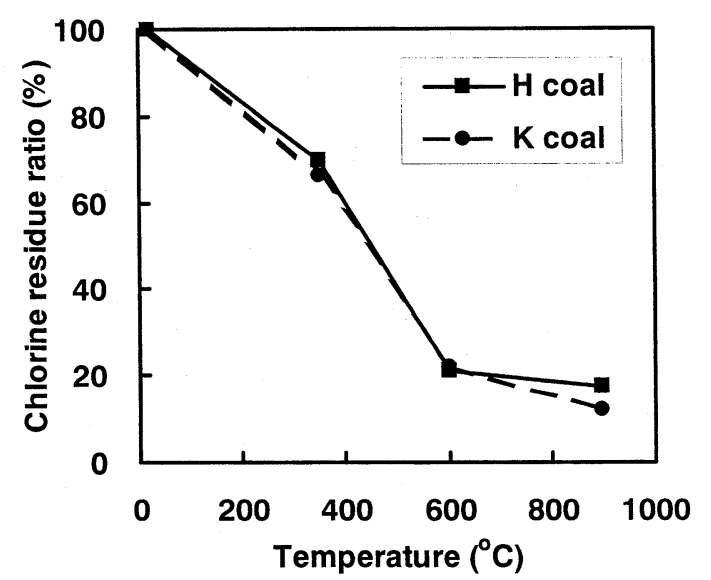

Fig. 7 Effect of heat treatment temperature on chlorine residue ratio $\left(5{ }^{\circ} \mathrm{C} / \mathrm{min}\right.$ )

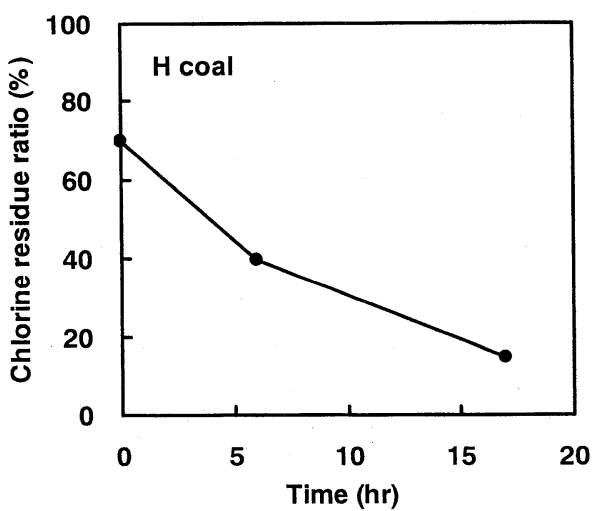

Fig. 8 Effect of soaking time at $360^{\circ} \mathrm{C}$ on chlorine residue ratio of $\mathrm{H}$ coal

Table 3 Effect of $\mathrm{NaCl}$ and $\mathrm{CaO}$ addition on chlorine residue ratio

\begin{tabular}{c|c|c|c|c|c|c}
\hline \multirow{2}{*}{ Coal } & \multicolumn{2}{|c|}{ Additives } & \multicolumn{2}{c|}{ Chlorine } & \multicolumn{2}{c}{ Residue ratio of chlorine derived from } \\
\cline { 2 - 7 } & $\begin{array}{c}\mathrm{NaCl} \\
(\%)\end{array}$ & $\begin{array}{c}\mathrm{CaO} \\
(\%)\end{array}$ & $\begin{array}{c}\mathrm{Cl}_{\mathrm{coal}+\mathrm{NaCl}} \\
(\mathrm{ppm})\end{array}$ & $\begin{array}{c}\mathrm{Cl}_{\text {coke }} \\
(\mathrm{ppm})\end{array}$ & $\begin{array}{c}\text { Coal } \\
(\%)\end{array}$ & $\begin{array}{c}\mathrm{NaCl} \\
(\%)\end{array}$ \\
\hline $\mathrm{F}$ & 0 & 0 & 210 & 97 & 34.6 & - \\
\hline $\mathrm{F}$ & 0 & 5 & 210 & 213 & 30.8 & 54.0 \\
\hline $\mathrm{F}$ & 1 & 0 & 6,280 & 4,320 & 80.8 & 95.4 \\
\hline $\mathrm{F}$ & 1 & 5 & 6,280 & 7,120 & \\
\hline
\end{tabular}

Heat treatment condition: $\mathrm{N}_{2}, 10^{\circ} \mathrm{C} / \mathrm{min}, 900{ }^{\circ} \mathrm{C}$ 
$\mathrm{H}_{2} \mathrm{O}$ の発生極大が $400 \sim 450{ }^{\circ} \mathrm{C}$ となる例も報告されている ${ }^{10)}$ さらに，石炭中に含まれる鉱物質の中には，石亮やアルミノ ケイ酸塩などのように, 高温で脱水反応が進行するものも存 在する ${ }^{11)}$ 。以上より, 石炭との共炭化により無機塩化物から の塩素の脱離が促進された理由は石炭熱分解過程で生じた $\mathrm{H}_{2} \mathrm{O}$ が原因であると推定されるが, さらに詳細な検討が必要 である。

また， $\mathrm{NaCl}$ に加えて $\mathrm{CaO}$ を 5 \% 添加すると，コークス中 塩素濃度が増大し, $\mathrm{NaCl}$ 由来塩素の残留率が上昇することが わかる。

Fig. 9 に熱処理温度と無機塩化物由来塩素の残留率の関係を 示す。図より，熱処理温度の上昇とともに無機塩化物由来塩 素の残留率は低下することがわかる。 $\mathrm{MgCl}_{2} \cdot 6 \mathrm{H}_{2} \mathrm{O}$ は $\mathrm{NaCl}$ お

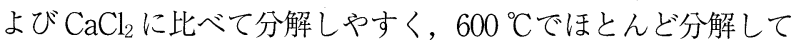
塩素が脱離してしまう。また, $900{ }^{\circ} \mathrm{Cにおいては,} \mathrm{NaCl}$ 由来 塩素の残留率が $\mathrm{CaCl}_{2}$ 由来塩素の残留率よりも低い。これは, 高温では $\mathrm{CaCl}_{2}$ が $\mathrm{NaCl}$ 上りも安定であるためと考えられる。

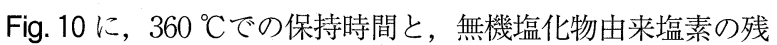

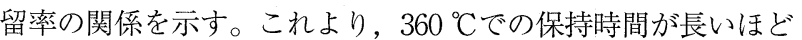
無機塩化物由来塩素の残留率が低下寸ることがわかる。 $360{ }^{\circ} \mathrm{C}$ での保持により無機塩化物由来塩素の残留率が低下する理由 は, この温度で石炭は徐々に熱分解が進行し， $\mathrm{H}_{2} \mathrm{O}$ が継続的 に供給されるためと考えられる。

\section{7 コークス化過程における原料炭中塩素の挙動}

以上の結果をもとに，石炭中の塩素が熱分解過程において どのような挙動を示すかを Fig. 11 のようなモデルで考えた。

\section{a) 石炭中塩素の存在形態（Fig. 11 a)）}

石炭中塩素の存在形態については，さまざまな説があるが, 有機塩素（共有結合塩素）の存在については否定的な見方が 強い ${ }^{1)}$ 。これは，もともと有機塩素が存在するとの仮説は石炭 中の一部の塩素が水に浸出しないという実験結果を根拠とし

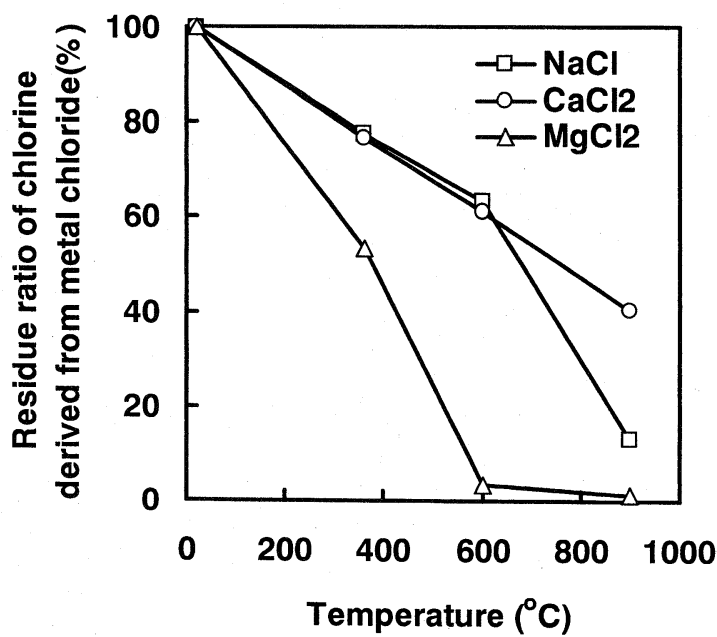

Fig. 9 Effect of heat treatment temperature on the residue ratio of chlorine derived from metal chloride (co-carbonized with $\mathrm{H}$ coal at $5{ }^{\circ} \mathrm{C} / \mathrm{min}$ )
ていたにもかかわらず，石炭を微粉砕して徹底的に浸出を繰 返すことにより，石炭中塩素のほとんど全てが水に浸出する ことが示されたためである ${ }^{4)}$ 6)。

無機塩素の存在形態としては，(1)結晶性の無機塩化物 (base hydrochloride: $\mathrm{NaCl}, \mathrm{KCl}, \mathrm{CaCl}_{2}$ など)，(2)有機塩酸塩 (organohydrochloride: 例えばアニリン塩酸塩など), (3)石炭ミ ク口細孔内水分中の塩化物イオンの 3 種類が考えられる。

Huggins $ら^{3)}$ はXAFS (X-ray absorption fine structure spectroscopy）を用いて石炭構造を検討し，石炭中に結晶性無機塩 化物は非常に僅かしか観察されず，石炭中塩素のほとんどは 有機塩素複合体（特に第 4 級アンモニウムイオン： $\mathrm{R}_{4} \mathrm{~N}^{+} \mathrm{Cl}^{-}$ の構造）により石炭マセラルのミクロ気孔の表面に水中の塩 化物イオンがトラップされていると述べている。また彼らは, 塩素濃度が高く，第 4 級アンモニウムイオンが塩化物イオン を補足するのに不十分な場合には，カルボキシル基やフェノ ール基などの負に帯電した含酸素官能基により石炭表面で捕 捉されたアルカリ金属などに塩素がトラップされている場合 もあると述べている。また坪内ら ${ }^{12)}$ も，石炭熱分解時に発生 する $\mathrm{HCl}$ 生成のピーク温度が, Huggins $ら^{3)}$ が用いた有機塩 酸塩（テトラサイクリン塩酸塩とセミカルバジド塩酸塩）の 熱分解ピークと一致することから，石炭中に有機塩酸塩構造 があることを示唆している。

一方で Hodges ら ${ }^{1)}$ は，第 4 級アンモニウムイオンに塩化 物イオンがトラップされた構造は陰イオン交換樹脂の構造に 近く, 強い相互作用のため塩化物イオンは水に浸出しにくく, 石炭中のほとんどの塩素が水溶性であるという実験事実と矛 盾していると述べて抢り, 石炭中塩素の主な存在形態は石炭 ミクロ細孔内水分中の塩化物イオンであると推定している。

テトラサイクリン塩酸塩やセミカルバジド塩酸塩は水溶性 であり，このような水溶性の有機塩酸塩がそのまま石炭中に あれば塩素が水侵出されることと矛盾しないが，ここでは Fig. 11 a) に示すように，石炭中の塩素は，石炭ミク口細孔内 水分中の塩化物イオンとして存在する ${ }^{1)}$ か, カルボキシル基

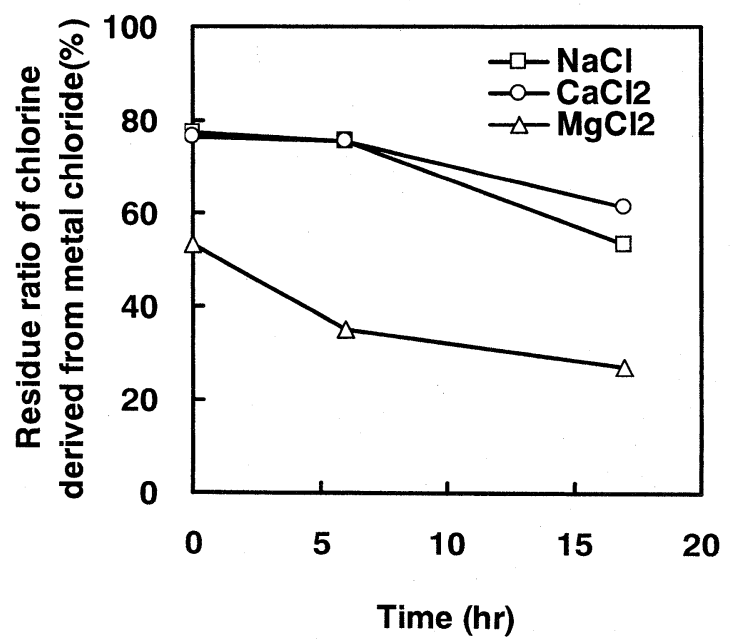

Fig. 10 Effect of soaking time at $360{ }^{\circ} \mathrm{C}$ on the residue ratio of chlorine derived from metal chloride (co-carbonized with $\mathrm{H}$ coal) 
a) $20^{\circ} \mathrm{C}$

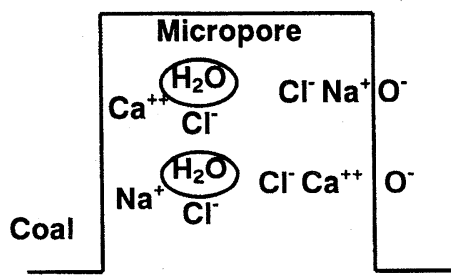

b) $100^{\circ} \mathrm{C}$; evaporation of moisture in coal micropores

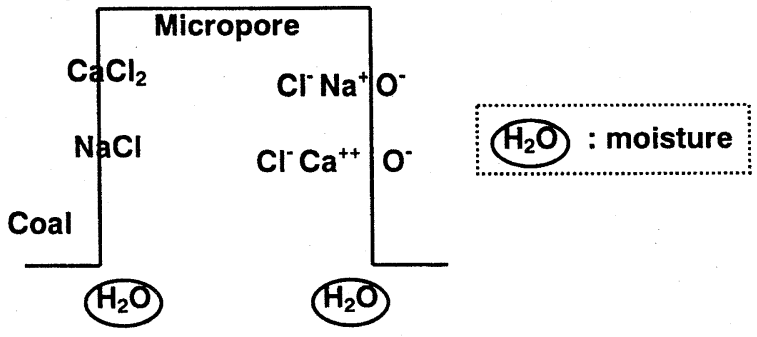

c) $300 \sim 900^{\circ} \mathrm{C}$; emission of $\mathrm{HCl}$ with the help of $\mathrm{H}_{2} \mathrm{O}$ evolution and fixation of $\mathrm{Cl}$ by Calcium

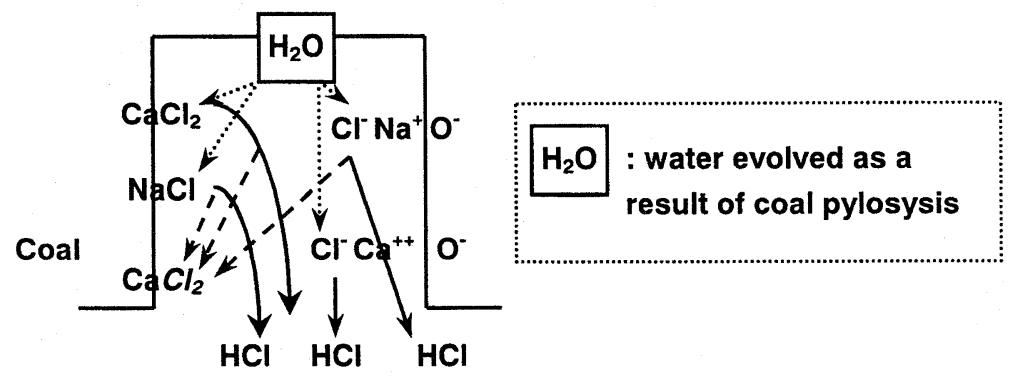

Fig. 11 Behavior of chlorine in coal during carbonization

やフェノール基などの負に帯電した含酸素官能基により石炭 表面で捕捉されたアルカリ金属などにトラップされている ${ }^{33}$ と考えた。

b）石炭ミク口細孔内の水の蒸発（Fig.11 b)）

温度が $100{ }^{\circ} \mathrm{C}$ 超えると石炭ミク口細孔内の物理吸着水が 蒸発してしまうため, 石炭ミク口細孔内水分中に存在する塩 化物イオンは, 一部は塩化ナトリウムや塩化カルシウムなど の金属塩化物の結晶として析出し, 一部は石炭の細孔内表面 にある正電荷に帯電した官能基あるいは原子にトラップされ ると考えられる。

c）石炭の熱分解過程 (Fig.11 c))

石炭の熱分解に伴い $\mathrm{H}_{2} \mathrm{O}$ が発生すると, 石炭表面にトラッ プされた塩素は $\mathrm{H}_{2} \mathrm{O}$ と反応して塩化水素として脱離すると考 えられる。また一方で, 脱離した塩化水素の一部は $\mathrm{Ca}$ と反応 し, $\mathrm{CaCl}_{2}$ として再度トラップされると考えられる。

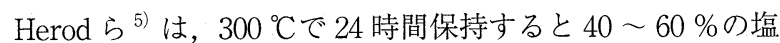
素が脱離し，石炭からの塩素の脱離はたいへんゆっくりとし た反応であると述べており，石炭からの塩素の脱離が遅い理 由は塩素（塩化物イオン）のミクロ気孔内拡散が律速である ためとしている。一方で, 本実験においても $360{ }^{\circ} \mathrm{C}$ で保持す
ると塩素残留率が低下したが，この温度では石炭の熱分解が ゆっくり進行するので, $\mathrm{H}_{2} \mathrm{O}$ の供給が律速となり塩素がゆっ くりと脱離するとも考えられる。今後, 熱分解過程における 塩素挙動に関しては, 特に石炭ミクロ細孔内の物理吸着水が 抜けた後における塩素の存在形態，および，石炭熱分解によ り生成する $\mathrm{H}_{2} \mathrm{O}$ と塩素の反応メカニズムの面から, さらに詳 細な検討が必要である。

\section{4. 結 言}

治金用コークス製造用原料炭中の塩素の定量，およびコー クス炉での石炭乾留 (石炭熱分解) 過程における塩素の挙動 について検討し，以下の結論を得た。

(1)用いた原料炭中の塩素濃度は約 $100 \sim 1,500 \mathrm{ppm}$ であり，原 料炭中塩素の多くが水溶性の無機塩素である。

(2)コークス中の塩素は多くが水溶性の無機塩素であり, Ca 含 有量が多い石炭ほどコークス中への塩素残留率が高い。これ は, 熱分解過程で脱離した塩素が塩化カルシウムとしてコー クス内にトラップされるためと考えられる。また実機製造コ 一クス中の塩素残留率は赤外加熱炉で調整したコークスより も高いが，これはガスの拡散距離が長く，トラップされる確 率が高いためと考えられる。

(3)石炭熱分解過程における塩素の脱離は極めて遅く, 昇温速 
度，保持時間はコークス中の塩素残留率に大きな影響を及ぼ す。

(4)無機塩化物を石炭と共炭化すると塩素の脱離が促進される。 これは, 石炭熱分解により生成する $\mathrm{H}_{2} \mathrm{O}$ が関与していると推 察されるが，今後詳細な検討が必要である。

\section{文 献; References}

1) Hodges, N. J., Ladner, W. R., and Martin, T. G., J. Inst. Energy, 56, 158 (1983)

2 ) Cross, P., Botting, A., Bircham, P., and Nicholls, K., Mine Quarry, 25(5), 33 (1996)

3 ) Huggins, F. E. and Huffman, G. P., Fuel, 74, 556 (1995)

4 ) Fynes, G., Herod, A. A., Hodges, N. J., Stokes, B. J., and Ladner, W. R., Fuel, 67, 822 (1988)

5 ) Herod, A. A., Hodges, N. J., Pritchard, E., and Smith, C. A., Fuel, 62, 1331 (1983)
6 ) Edgcombe, L. J., Fuel, 35, 38 (1956)

7 ) Daybell, G. N. and Pringle, W. J. S., Fuel, 37, 283 (1958)

8 ) Mianowski, A. and Koszorek, A., Polish J. Appl. Chem., 39, 295 (1995)

9 ）前一広, 日本エネルギー学会誌，75, 167 (1996) : Mae, K., J.Jpn. Inst. Energy, 75, 167 (1996)

10）大内公耳，本田英昌，燃料協会誌，40, 845 （1961）： Ouchi, K., Honda, H., Nenryo Kyokaishi, 40, 845 (1961)

11）神谷佳男, 真田雄三, 富田彰, 石炭と重質油 その化学 と応用 (講談社), p. 223 (1979) :Kamiya, Y., Sanada, Y., Tomita, A., Sekitan to Jushitsuyu (Kodansha), p.123 (1979)

12）坪内直人, 王 延輝, 大塚康夫, 第 39 回石炭科学会議予 稿集, 171 (2002) : Tsubouchi, N., Wang, Y., Otsuka, Y., 39th Sekitankagakukaigi Yokoshu, p. 171 (2002) 